Part of Journal of Research of the National Bureau of Standards, Volume 21, August 1938

\title{
ELECTROLYTIC RESISTORS FOR DIRECT-CURRENT - APPLICATIONS IN MEASURING TEMPERATURES
}

\author{
By D. Norman Craig
}

\section{ABSTRACT}

An improved electrolytic resistor, developed primarily for temperature indicators on radio meteorographs, is described. On such instruments variable unidirectional currents are employed. Resistors to be used successfully in such applications require (1) large temperature coefficient, (2) low freezing point, (3) light weight, (4) reversibility, (5) stability of calibration, (6) hermetical sealing, (7) high resistance with minimum inductance and capacitance, and (8) rapid response to temperature changes. The resistor consists of copper electrodes in a capillary tube filled with a solution of cuprous chloride, hydrochloric acid, and ethyl alcohol. Various proportions may be used in obtaining solutions which will not freeze at $-75^{\circ} \mathrm{C}$. The alcohol affords a convenient means of adjusting the resistance of a particular resistor to the desired value. Within reasonable limits of impressed voltage, the resistors have been found reliable over a temperature range of $+30^{\circ}$ to $-75^{\circ} \mathrm{C}$. They respond satisfactorily to changes in temperature and hold their calibration for periods of time much in excess of that required for a flight. Ratios of the resistances $R_{t} / R_{0}$ measured with direct current agree with those measured with alternating current. Temperature indications are believed to be accurate within $1^{\circ} \mathrm{C}$, even at the lowest temperature.

\section{CONTENTS}

II. Experimental procedure

1. Solutions used in the resistors

2. Measurement of resistivities of solutions $\ldots \ldots$

3. Preparation of resistors._.

4. Temperature control for calibration and tests _._.

III. Experimental results _..._.

1. Resistivities of solutions used in the resistors $\ldots \ldots \ldots \ldots 229$

2 . Repeated measurements of d-c resistance at a fixed temperature 229

3. Comparison of two series of temperature measurements _._. _ 229

4. Comparison of a-c and d-c values of resistance

5. Effect of time and impressed voltage on resistance ratios _... 231

6. Reliability of temperature calibration _ _ _ _

IV. Conclusion _.....

\section{INTRODUCTION}

Electrolytic resistors of many types and kinds have been made in the past, but most of them were subject to limitations of polarization, gassing, or lack of permanence. The use of electrolytic resistors has been confined, therefore, to applications in which these detrimental features were not objectionable or for which they possessed some positive advantages. Because of polarization and gassing when used with direct currents, electrolytic resistors are more generally asso- 
ciated with a-c circuits. However, certain types may be used successfully in d-c circuits, and this paper describes a type developed primarily for temperature indicators on radio meteorographs where variable direct currents are used.

Electrolytic resistors for this purpose require (1) a large temperature coefficient, (2) a freezing point below any probable atmospheric temperature, (3) light weight, (4) reversibility of electrochemical reactions, (5) stability of calibration, (6) hermetical sealing, (7) high resistance with a minimum of inductance and capacitance, and (8) rapid response to temperature changes. Electrolytic resistors developed especially for this purpose are described in papers by Diamond, Hinman, and Dunmore. ${ }^{1}$ The first resistor described by them consisted of a capillary column of sulfuric acid of 1.3 specific gravity, which gave the necessary resistance variation and rapidity of response down to $-70^{\circ} \mathrm{C}$. This, however, was not satisfactory in respect to points 2,4 , and 5 above. As stated in the papers ${ }^{1}$ cited, the present author collaborated in the work by developing an improved electrolyte for this type of capillary electrolytic thermometer. This improvement is described in the present paper.

Although a number of electrolytes might be chosen which would fulfill satisfactorily the requirements of resistance and large temperature coefficient, the other requirements limit the choice of materials. Certain copper solutions, described below, to which ethyl alcohol has been added in sufficient quantities to depress the freezing point, have been found to be well adapted to the purpose. The alcohol affords a convenient means of adjusting the resistivity of the solution to the most advantageous value for any particular problem.

The use of electrolytic resistors such as those described in this paper is by no means limited to radio meteorographs. Because of their stability and high-temperature coefficients they may find application to the control of temperatures when the current passing through the cell is very small. Preliminary experiments using alternating current and such a cell for controlling temperature in a water bath in conjunction with a radio amplifier and small thyratron showed that regulation to about $0.005^{\circ} \mathrm{C}$ could be obtained and this is probably susceptible of improvement. Because of their high resistance with low capacitance and inductance they should find other applications where such characteristics are desirable.

Mention was made in the papers previously cited of copper solutions, and a brief description of the improved solution was given on page 381 of the third (1938) paper. Early designs of electrolytic resistors employing platinum electrodes in sulfuric acid solutions proved to be somewhat unsatisfactory because of polarization and the evolution of gas, the latter requiring that the resistors be provided with expansion chambers or vents. Gassing was naturally reduced when copper electrodes were used in copper sulfate solutions, but the limited solubility of copper sulfate in sulfuric acid particularly at the low temperatures, limited the development of such resistors. Improved performance and simplification were provided, however, by the

' H. Diamond, W. S. Hinman, and F. W. Dunmore, The development of a radio-meteorograph system for the Navy Department. Bul. Am. Meteorological Soc. 18, 73 (1937).

H. Diamond, W. S. Hinman, and F. W. Dunmore. A radio-meteorograph system with special aeronautical applications. J. Inst. Aero. Sci. 4, 241-248 (1937).

H. Diamond, W. S. Hinman, and F. W. Dunmore, A method for the investigation of upper-air phenomena and its application to radio meteorography. J. Research NBS 20, 369 (1938). RP1082. 
use of hydrochloric acid, ethyl alcohol, and cuprous chloride, as described in this paper.

\section{EXPERIMENTAL PROCEDURE}

\section{SOLUTIONS USED IN THE RESISTORS}

The solutions used in the resistors contained varying amounts of hydrochloric acid (36\%; sp gr 1.18), ethyl alcohol (95\%), and cuprous chloride, as shown in table 1.

TABLE 1.-Resistivities of solutions containing concentrated hydrochloric acid, ethyl alcohol, and cuprous chloride

\begin{tabular}{|c|c|c|c|c|c|c|c|}
\hline \multirow{2}{*}{ Solution number } & \multicolumn{3}{|c|}{ Composition of solution } & \multicolumn{2}{|c|}{ Resistivity $\rho$} & \multirow{2}{*}{$\rho_{00}^{\circ} \mathrm{C}-\rho_{300} \mathrm{C}$} & \multirow{2}{*}{$\rho_{00}^{\circ} \mathrm{C}-\rho_{30}^{\circ} \mathrm{C}$} \\
\hline & $\mathrm{HCl}$ & $\mathrm{C}_{2} \mathrm{H}_{6} \mathrm{OH}$ & $\mathrm{CuCl}$ & $30^{\circ} \mathrm{C}$ & $0^{\circ} \mathrm{C}$ & & \\
\hline$\ldots$ & $\begin{array}{r}\mathrm{ml}_{40} \\
35 \\
30\end{array}$ & $\begin{array}{cr}\mathrm{ml} & \\
35 \\
40 \\
45\end{array}$ & $\begin{array}{r}\mathrm{g} \\
2 \\
2 \\
2\end{array}$ & $\begin{array}{r}\text { ohm-cm } \\
5.4 \\
6.9 \\
8.8\end{array}$ & $\begin{array}{r}\text { ohm-em } \\
10.3 \\
13.6\end{array}$ & $\begin{array}{r}\text { ohm-cm } \\
4.9 \\
6.7\end{array}$ & $\begin{array}{l}1.91 \\
1.97\end{array}$ \\
\hline 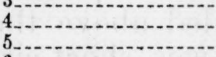 & $\begin{array}{l}30 \\
25 \\
20\end{array}$ & $\begin{array}{l}40 \\
50 \\
55\end{array}$ & $\begin{array}{l}2 \\
2 \\
2\end{array}$ & $\begin{array}{r}\text { 8.8 } \\
11.3 \\
14.9\end{array}$ & $\begin{array}{l}23.1 \\
31.5\end{array}$ & $\begin{array}{l}11.8 \\
16.6\end{array}$ & $\begin{array}{r}2.05 \\
2.12\end{array}$ \\
\hline-1 & 15 & & 2 & 20.7 & 44.5 & 23.8 & 2.15 \\
\hline
\end{tabular}

The hydrochloric acid and alcohol mixtures were prepared by volume; the sum of the volumes taken was $75 \mathrm{ml}$ to which $2 \mathrm{~g}$ of cuprous chloride were added. The solutions subsequently were kept in tightly stoppered flasks to avoid undue exposure to the air. They, however, contained some cupric salt, part of which was initially present in the cuprous chloride and part formed by unavoidable exposure of the solutions to the air either while being prepared or used. There is therefore some uncertainty in the concentration of copper in these solutions. The presence of the cupric ion in the solutions necessitates calibration of the resistors after reduction of the cupric ion to cuprous ion by the copper electrodes. When reduction is completed the solutions become colorless.

\section{MEASUREMENT OF RESISTIVITIES OF SOLUTIONS}

The resistivities of the solutions were measured on a bridge using 60 -cycle current and an a-c galvanometer as the detector. The ratio arms were equal and each consisted of a 100,000-ohm standard resistor. The other arms consisted of a variable resistor and the cell containing the solution to be measured. The accuracy of the measurements on this bridge was determined by comparisons with resistors of low inductance and capacitance which were standardized by other sections of the Bureau. When making a-c measurements the error in measuring $100,000-\mathrm{ohm}$ resistors did not exceed 3 percent at 60 cycles. The error in measuring $100,000-\mathrm{ohm}$ resistors with direct current did not exceed 0.03 percent. Most of the measurements on electroly tic resistors given in this paper are d-c measurements.

A specially designed cell was used for measuring the resistivity of the solutions. It consisted of a test tube which contained the solution to be measured, and a capillary tube, supported at the top, dipped into this solution. The electrodes were copper, one being in 
an enlarged portion of the capillary and the other in the free liquid near the lower end of the capillary. This arrangement was convenient for making exploratory measurements at extremely low temperatures and permitted measurements to be made under conditions similar to those obtaining in the finished resistors. The constant of this cell was determined with sufficient accuracy by comparative measurements with a conductivity cell of the customary type for which the constant was known.

\section{PREPARATION OF RESISTORS}

Capillary $U$ tubes of approximately $1 \mathrm{~mm}$ bore served to hold the solution and electrodes. A small bulb was blown on each side of the $U$ tubes and the length of the capillary joining the bulbs depended upon the resistance intended for each tube. The electrodes used in the resistors were pieces of size 18 AWG annealed copper wire. The tubes were filled to the upper end of the bulbs with a small pipette drawn out to a fine capillary. The electrodes were inserted into the capillaries of the $U$ tube and terminated in the bulbs. They were held in place and the tubes sealed with DeKhotinsky cement. This method of sealing the resistors proved to be satisfactory for the present work since a sufficient length of capillary was provided above the bulbs to permit satisfactory sealing. Each resistor was short-circuited when not in use.

In those cases where permanency is important a copper to glass seal would be preferable, and can be made. When permanent copper to glass seals are made one terminal can be copper wire, and the other terminal a small copper tube to permit filling the cell after the copper to glass seals have been made. When the cell is completed it is evacuated and filled, the copper tube is then closed at its upper extremity. A resistor of the type used on meteorographs is shown in figure 1 .

The resistance measurements employing direct current were made on the same bridge as the resistivity measurements.

For the d-c measurements the bridge was provided with a sensitive d-c galvanometer and a source of variable voltage and in some cases a low-resistance microammeter was in series with the resistor so that the current and voltage could be correlated.

\section{TEMPERATURE CONTROL FOR CALIBRATION AND TESTS}

Measurements above $0^{\circ} \mathrm{C}$ were made with the resistors immersed in a beaker of water which was surrounded by a larger beaker and the intervening space filled with loose cotton. The stirring was done manually and the temperature was maintained sufficiently constant for the purpose by the addition of small quantities of hot or cold water. The temperature was measured with a mercury thermometer graduated to $0.1^{\circ} \mathrm{C}$. The measurements at $0^{\circ} \mathrm{C}$ were made with the resistors immersed in mixtures of ice and water. Measurements below $0^{\circ} \mathrm{C}$ were made with the resistors immersed in ethyl alcohol contained in a clear-glass Dewar to which solid $\mathrm{CO}_{2}$ was added as required. Six or more observations of temperature and resistance were made while the temperature of the alcohol was held close to the average value by the addition of small quantities of $\mathrm{CO}_{2}$ and frequent stirring. The temperatures below $0^{\circ} \mathrm{C}$ were estimated to $0.1^{\circ} \mathrm{C}$ with a toluene thermometer graduated to $1^{\circ} \mathrm{C}$. 


$$
V
$$




\section{EXPERIMENTAL RESULTS}

\section{RESISTIVITIES OF SOLUTIONS USED IN THE RESISTORS}

The composition of the solutions investigated and their resistivities at $30.0^{\circ}$ and $0^{\circ} \mathrm{C}$ are given in table 1 . The resistivity values at $30^{\circ} \mathrm{C}$ were measured with 60-cycle current, employing the resistivity cell previously described. The resistivities at $0^{\circ}$ were calculated by multiplying the resistivity values at $30^{\circ} \mathrm{C}$ by the ratio of the a-c resistances at $0^{\circ}$ and $30^{\circ}$ of resistors containing the respective solutions.

The resistivity of the solutions varies comparatively little with changes in the copper content. For this reason the data given in table 1 can serve as a guide in making resistors of specified values notwithstanding the fact that a small amount of cupric ion was known to be present when the measurements were made.

\section{REPEATED MEASUREMENTS OF D-C RESISTANCE AT A FIXED TEMPERATURE}

In the course of measurements at many different temperatures a resistor was returned repeatedly to a fixed temperature, $0^{\circ} \mathrm{C}$, to determine how well successive measurements would agree with the first measurement made at this temperature. In actual service the resistor would be calibrated by initital measurements and it is important therefore to show how well this calibration can be depended upon when direct current flows through the resistor continuously and it is exposed to rapidly changing temperatures. The results given in table 2 show that during 114 hours of continuous operation, more than twenty-five times the service period required, the resistor held its calibration within $1^{\circ} \mathrm{C}$. The initial measurement at $0^{\circ} \mathrm{C}$ was made $1 \frac{11}{4}$ hours after beginning the observations.

TABLE 2.-Repeated measurements on resistor $B$ at a fixed temperature, $0^{\circ} C$

[Direct-current measurements, impressed voltage 0.82 volts; solution 3]

\begin{tabular}{|c|c|c|c|}
\hline \multirow{2}{*}{ Elapsed time } & \multirow{2}{*}{$\begin{array}{l}\text { Measured } \\
\text { resistance }\end{array}$} & \multicolumn{2}{|c|}{$\begin{array}{l}\text { Deviation from first meas- } \\
\text { urement at } 0^{\circ} \mathrm{C}\end{array}$} \\
\hline & & Resistance & $\begin{array}{l}\text { Equivalent } \\
\text { temperature }\end{array}$ \\
\hline $\begin{array}{l}\text { Hours } \\
11 / 4 \\
181 / 4 \\
68 \\
1141 / 2\end{array}$ & $\begin{array}{l}\text { Ohms } \\
26,950 \\
26,820 \\
26,780 \\
26,590 \\
26,240 \\
26,780\end{array}$ & $\begin{array}{r}\text { Percent } \\
0.48 \\
1.63 \\
2.74 \\
.63\end{array}$ & $\begin{array}{r} \\
0.16 \\
.21 \\
.45 \\
.91 \\
.21\end{array}$ \\
\hline Average & & - & .39 \\
\hline
\end{tabular}

\section{COMPARISON OF TWO SERIES OF TEMPERATURE} MEASUREMENTS

Two series of measurements were made using the same resistor in order to judge how accurately the second series of resistance measurements may be expected to indicate temperatures in the range in which the resistors are expected to operate. The results of these measurements are given in table 3 . Since the observed temperatures in the 
second series of measurements were not the same as those in the first series, the resistances given in the table for the second series were read from a large graph made by plotting the observed temperatures against the logarithms of the observed resistances. The differences in the two series of measurements are given in terms of resistance and temperature in columns 4 and 5 , respectively. It may be observed that there is a progressive increase in the resistance difference as the temperature is lowered; however, the temperature coefficient of the resistance increases rapidly at the lower temperatures and consequently the temperature differences given in the last column for the two series of measurements do not exceed $1^{\circ} \mathrm{C}$.

TABLE 3.-Comparison of two series of measuremenis using the same resistor [Observed values for the first series are compared with corresponding interpolated values of a second series. 0.5 volt across resistor]

\begin{tabular}{|c|c|c|c|c|}
\hline \multicolumn{2}{|l|}{ First series } & \multirow{2}{*}{$\begin{array}{l}\text { Second } \\
\text { series- } \\
\text { interpolated }^{1} \\
\text { resistance }\end{array}$} & \multicolumn{2}{|c|}{$\begin{array}{l}\text { Difference (first minus } \\
\text { second series) }\end{array}$} \\
\hline Observed temperature & $\begin{array}{l}\text { Observed } \\
\text { resistance }\end{array}$ & & Resistance & $\begin{array}{l}\text { Equivalent } \\
\text { temperature }\end{array}$ \\
\hline 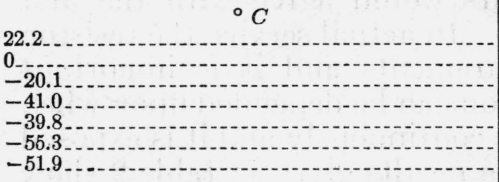 & $\begin{array}{r}\text { Ohms } \\
12,275 \\
21,065 \\
41,300 \\
99,200 \\
93,100 \\
215,000 \\
176,000\end{array}$ & $\begin{array}{r}\text { Ohms } \\
12,100 \\
20,695 \\
40,800 \\
97,500 \\
91,600 \\
211,000 \\
172,000\end{array}$ & $\begin{array}{r}\text { Ohms } \\
175 \\
370 \\
500 \\
1,700 \\
1,500 \\
4,000 \\
4,000\end{array}$ & $\begin{array}{r}0.6 \\
.4 \\
.2 \\
.5 \\
.3 \\
.2 \\
.4\end{array}$ \\
\hline
\end{tabular}

${ }^{1}$ Interpolated resistances in this column correspond to the observed temperatures in the first column. Each series of measurements occupied about 5 hours during which current was passing continuously through the resistor. The first series of measurements was completed 3 days before beginning the second, and the resistor was short-circuited during that interval.

\section{COMPARISON OF A-C AND D-C VALUES OF RESISTANCE}

Since it is commonly observed that the d-c resistance of electrolytic cells differ from the a-c, a number of measurements were made to study the magnitude of these differences. It was further observed, as may be expected, that the d-c resistance varies with the impressed voltage. Typical experimental data for these resistors are given in

TABLE 4.-Comparison of $a-c$ and $d-c$ values of resistance and their equivalent variations in temperature

[Resistor containing solution 5. The a-c values are taken as the basis of measurement]

\begin{tabular}{|c|c|c|c|c|}
\hline \multirow[b]{2}{*}{ Impressed voltage } & \multicolumn{2}{|c|}{ Measurements at $30^{\circ} \mathrm{C}$} & \multicolumn{2}{|c|}{ Measurements at $0^{\circ} \mathrm{C}$} \\
\hline & Resistance & $\begin{array}{l}\text { Equivalent } \\
\text { variation in } \\
\text { temperature }\end{array}$ & Resistance & $\begin{array}{l}\text { Equivalent } \\
\text { variation in } \\
\text { temperature }\end{array}$ \\
\hline 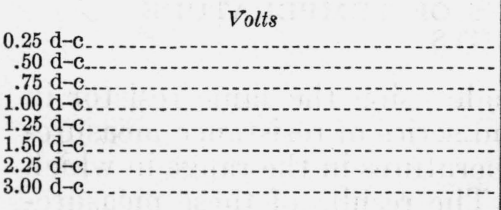 & $\begin{array}{r}\text { Ohms } \\
23,680 \\
22,410 \\
21,850 \\
21,710 \\
21,570 \\
21,440 \\
-\end{array}$ & $\begin{array}{r}{ }^{\circ} \mathrm{C} \\
7.3 \\
4.2 \\
2.9 \\
2.8 \\
2.2 \\
1.9 \\
\end{array}$ & $\begin{array}{l}\text { Ohms } \\
54,900 \\
50,300 \\
48,700 \\
47,700 \\
47,340 \\
47,030 \\
46,360 \\
46,070\end{array}$ & $\begin{array}{l}8.0 \\
4.6 \\
3.4 \\
2.6 \\
2.3 \\
2.1 \\
1.6 \\
1.4\end{array}$ \\
\hline $2 a-c \ldots$ & 20,660 & 0 & 44,240 & 0 \\
\hline
\end{tabular}


table 4. The data indicate that as the voltage is increased the d-c resistance approaches the a-c value, and the equivalent variation in temperature becomes smaller. How closely the d-c values may be expected to agree with the a-c values depends upon the voltage impressed across the resistor. It may be mentioned, however, that in certain applications where the resistor is calibrated with direct current, agreement between the a-c and d-c resistance is not required in order to indicate temperatures correctly.

\section{EFFECT OF TIME AND IMPRESSED VOLTAGE ON RESISTANCE RATIOS}

Before using an electrolytic resistor for a temperature-indicating device it is of course necessary to know the relation between its resistance and temperature, and its usefulness depends upon how well and how long the relation holds under operating conditions. For the purposes of this paper, the relation between resistance and temperature may be expressed by the value of the ratio of the resistance at the particular temperature to the resistance at some reference temperature, for example $\left(R_{t^{\circ} \mathrm{C}} / R_{22.5^{\circ} \mathrm{C}}\right)=1.67$ means that the resistance at $t^{\circ} \mathrm{C}$ is 1.67 times the resistance at $22.5^{\circ} \mathrm{C}$. Although the data given in table 5 show the ratio $R_{0} / R_{22.5}$ to be constant for all impressed voltages from 0.05 to 1.25 volts after 6 hours of constant use, departures from a constant ratio became evident after 18 hours when the impressed voltage was below 0.5 volt. When voltages higher than 0.5 volt were employed, the ratio, $R_{0} / R_{22.5}$ was in excellent agreement with previously determined values notwithstanding the fact that a direct current of about $50 \mu \mathrm{a}$ had passed through the cell for 18 hours.

The table shows that as the impressed voltage is increased the measured resistance diminishes slightly. This may be caused by one or all of several effects produced by the current. Localized heating would decrease the ohmic resistance. A small but constant counter emf would also result in lowered measured resistances with increased impressed voltages. Whatever the cause, a plot of voltage against current is essentially linear, with a small intercept of a few hundredths of a volt on the voltage axis.

TABLE 5.-Reliability of the ratios of resistance at $0^{\circ}$ and $22.5^{\circ} \mathrm{C}$ for various impressed voltages and times of observation

[Resistor containing solution 2]

\begin{tabular}{|c|c|c|c|c|c|}
\hline \multirow{2}{*}{ Impressed voltage } & \multirow{2}{*}{$\begin{array}{l}\text { Resistance } \\
\text { at } 0^{\circ} \mathrm{C} \\
.\end{array}$} & \multicolumn{2}{|c|}{ Resistance after $6 \mathrm{hr}$} & \multicolumn{2}{|c|}{ Resistance after $18 \mathrm{hr}$} \\
\hline & & $22.5^{\circ} \mathrm{C}$ & $R_{0} / R_{22.8^{\circ} \mathrm{C}}$ & $22.5^{\circ} \mathrm{C}$ & $R_{0} / R_{22.5^{\circ} \mathrm{C}}$ \\
\hline 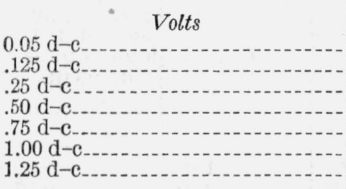 & $\begin{array}{l}\text { Ohms } \\
22,500 \\
20,800 \\
20,900 \\
20,350 \\
19,870 \\
19,630 \\
19,500\end{array}$ & $\begin{array}{l}\text { Ohms } \\
13,432 \\
12,437 \\
12,457 \\
12,050 \\
11,811 \\
11,681 \\
11,592\end{array}$ & $\begin{array}{l}\text { 1. } 67 \\
\text { 1. } 67 \\
\text { 1. } 68 \\
\text { 1. } 69 \\
\text { 1. } 68 \\
\text { 1. } 68 \\
\text { 1. } 68\end{array}$ & $\begin{array}{r}\text { Ohms } \\
21,385 \\
15,160 \\
13,152 \\
12,229 \\
11,897 \\
11,727 \\
11,636\end{array}$ & $\begin{array}{l}1.05 \\
\text { 1. } 37 \\
\text { 1. } 59 \\
\text { 1. } 65 \\
\text { 1. } 67 \\
\text { 1. } 67 \\
\text { 1. } 68\end{array}$ \\
\hline$a-c_{-}-$ & 19,085 & 11,390 & 1. 67 & 11,390 & 1. 67 \\
\hline
\end{tabular}

Table 5 shows also a comparison of $\mathrm{d}-\mathrm{c}$ and a-c measurements using the same resistor. Although the a-c and d-c resistances are 
not in perfect agreement, the ratios $R_{0} / R_{22.5}$ are in excellent agreement. This is a matter of importance for temperature measurements with radio circuits in which part of the current is unidirectional. If the calibration is made with direct current and the instrument is subsequently used with the same impressed d-c voltage, the calibration is reliable for a longer period of time than is required for a flight. Comparisons of resistance ratios obtained from a-c and d-c measurements are given for a wide range of temperatures in the next section.

\section{RELIABILITY OF TEMPERATURE CALIBRATION}

In table 6 are given the comparative temperatures for a-c and d-c measurements based on actual measurements of temperature. In the first column specified ratios $R_{t} / R_{0}$ are given. In the second column the temperatures corresponding to these ratios are given on the basis of a-c measurements. Three columns of measurements are given for the d-c values obtained with impressed voltages of $1.25,0.5$, and 0.25 volts, respectively. Agreement with the a-c values is satisfactory for all, but as a precaution voltages less than 1.0 volt are not recommended. On the radio meteorograph the voltage applied is always greater than 1 volt.

In table 7 the allowable variation in the ratio, equivalent to $1^{\circ} \mathrm{C}$, based on a-c measurements is given for the temperature range $+30^{\circ}$ to $-75^{\circ} \mathrm{C}$.

TABLE 6.-Comparison of resistance ratios with interpolated temperatures based on $a-c$ and $d-c$ measurements at $0^{\circ} C$

[Resistor containing solution 2]

\begin{tabular}{|c|c|c|c|c|}
\hline \multirow{2}{*}{ Resistance ratio $R_{t} / R_{0}$} & \multirow{2}{*}{$\begin{array}{l}\text { Using alter- } \\
\text { nating cur- } \\
\text { rent }\end{array}$} & \multicolumn{3}{|c|}{ Using dirrect current } \\
\hline & & $1.25 \mathrm{v}$ & $0.5 \mathrm{v}$ & $0.25 \mathrm{v}$ \\
\hline 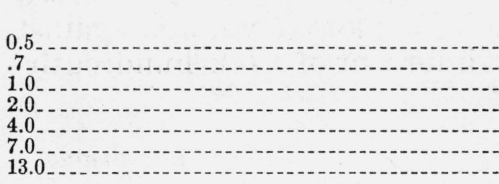 & $\begin{array}{r}{ }^{\circ} C_{30.5} \\
14.5 \\
0.0 \\
-21.5 \\
-39.4 \\
-50.6 \\
-\end{array}$ & $\begin{array}{r}{ }^{\circ} C \\
30.1 \\
14.3 \\
0.0 \\
-21.0 \\
-38.2 \\
-49.2 \\
-59.2\end{array}$ & $\begin{array}{r}{ }^{\circ} C \\
29.4 \\
14.3 \\
0.0 \\
-20.5 \\
-37.5 \\
-48.8 \\
-58.7\end{array}$ & $\begin{array}{r}{ }^{\circ} C \\
28.3 \\
13.8 \\
0.0 \\
-20.3 \\
-37.2 \\
-48.3 \\
-58.2\end{array}$ \\
\hline
\end{tabular}

TABLE 7.-Comparisons of observed temperatures with measured resistance ratios based on the resistance at $30^{\circ} \mathrm{C}$

[Resistor containing solution 5]

\begin{tabular}{|c|c|c|c|c|}
\hline \multirow{2}{*}{ Measured temperature } & \multicolumn{3}{|c|}{ Ratio of resistances $R_{t} / R_{30}$} & \multirow{2}{*}{$\begin{array}{l}\text { Allowable } \\
\text { variation in } \\
\text { ratio, equiv- } \\
\text { alent to } 1^{\circ} \mathrm{C} \\
\text { from a-c meas- } \\
\text { urements }\end{array}$} \\
\hline & $1.5 \mathrm{v}$ & $1.0 \mathrm{v}$ & $0.5 \mathrm{v}$ & \\
\hline $\begin{array}{l}{ }^{\circ} \mathrm{C} \\
30.0 \\
0\end{array}$ & $\begin{array}{c}1.0 \\
2.19 \\
4.04 \\
9.4 \\
20.4 \\
46.2 \\
122\end{array}$ & $\begin{array}{c}1.0 \\
2.20 \\
4.03 \\
9.18 \\
20.8 \\
47.6 \\
122\end{array}$ & $\begin{array}{rl} & 1.0 \\
& 2.24 \\
& 4.18 \\
\mathrm{2} & 10.0 \\
\mathrm{2} & 22.4 \\
\mathrm{~A} & 52.5 \\
\mathrm{a} & 140\end{array}$ & $\begin{array}{l}0.07 \\
.36 \\
.41 \\
1.1 \\
2.6 \\
7.2\end{array}$ \\
\hline
\end{tabular}

- All ratios except those indicated are concordant within the limit of variation equivalent to $1^{\circ} \mathrm{C}$. The aximum variation occurring at $-75^{\circ}$ is less than the equivalent of $2.5^{\circ} \mathrm{C}$. 
Errors greater than $1^{\circ} \mathrm{C}$ appear when the temperature is $-37^{\circ} \mathrm{C}$ and the impressed voltage 0.5 volt. It is desirable therefore that the impressed voltage should be 1.0 volt or more. The lowest temperature shown in this table, $-75^{\circ} \mathrm{C}$, is believed to be sufficiently low for any atmospheric temperature likely to be encountered. In the course of a large number of measurements at low temperatures no abnormalities were observed in the resistance measurements which were to be associated with freezing of the electrolyte or precipitation of cuprous chloride. Further evidence that the solutions comply with the temperature requirement was obtained by sealing samples of each solution together with a short piece of copper wire in small tubes, which when completely submerged in alcohol containing solid $\mathrm{CO}_{2}$, and vigorously shaken, showed no evidence of freezing of the solution, or the precipitation of cuprous chloride.

\section{CONCLUSION}

Resistors of the type described have found use in numerous flights which have been made. Some of the resistors returned after the completion of the flight have been recalibrated and good agreement found between the initial and subsequent calibrations.

It is believed that these resistors possess properties which should make them useful in other applications on either a-c or d-c circuits, where high resistance coupled with small inductance and capacitance are desired. The high-temperature coefficient is desirable in problems of temperature control.

Washington, May 2, 1938. 